\title{
Changes in Outer Membrane Proteins of Benzalkonium Chloride Adapted Pseudomonas Aeruginosa and Mutations in GyrA and ParC Genes
}

\author{
MOHAMED E. OSMAN, Ph.D.*; HODA H. EL-HENDAWY, Ph.D.*; AHMED M. HASSAN, Ph.D**; \\ SAID M. ABD EL-ALL, Ph.D.** and DINA E. MAHMOUD, M.Sc.**
}

The Department of Botany \& Microbiology, Faculty of Science, Helwan University* and

National Organization for Drug Control \& Research**, Egypt

\begin{abstract}
Background: Benzalkonium Chloride (BC) is widely used in hospitals, industry and cosmetics. Adaptation of Pseudomonas aeruginosa to $\mathrm{BC}$ was increased. This adaptation may lead to the emergence of cross-resistance to other disinfectants and antibiotics. Little attention has been focused on the resistant mechanisms.

Aim of Study: Examination of mutations in the Quinoloneresistance-Determining Region (QRDR) of GyrA and ParC genes and alterations of Outer-Membrane Proteins (OMPs) in Benzalkonium Chloride (BC)-adapted Pseudomonas aeruginosa isolates.
\end{abstract}

Material and Methods: GyrA and ParC genes of the BCadapted $\mathrm{P}$. aeruginosa isolate and the wild-type strain ATCC 15442 were amplified by Polymerase-Chain-Reaction (PCR) and sequenced. OMPs of these isolates were also analyzed by Sodium Dodecyl Sulfate-Polyacrylamide Gel Electrophoresis (SDS-PAGE) in the presence and absence of permeabilizer disodium Ethylenediamine-Tetraacetate (EDTA) to investigate the variations.

Results: The results manifested a single mutation in both GyrA (Thr-83-Ile) and ParC (Ser-87-Leu). In SDS-PAGE, one band with molecular weight of $52.23 \mathrm{kDa}$ was detected in all samples. Seven bands with molecular weights of 71.44 , $38.48,36.01,33.03,26.17,21.14$ and $6.35 \mathrm{kDa}$ were stable in both ATCC 15442 and treated isolate. Also, seven bands with molecular weights of $120.83,90.89,79.72,44.58,28.91$, 16.12 and $12.49 \mathrm{kDa}$ were newly induced in the treated isolate.

Conclusions: These results revealed that mutations in GyrA and ParC genes, and alteration of OMPs contributed to the adaptation of $\mathrm{P}$. aeruginosa to $\mathrm{BC}$, co-operating with efflux pump over-expression.

Key Words: Benzalkonium chloride - Pseudomonas aeruginosa - GyrA, ParC-Mutations - Outer membrane proteins - SDS - PAGE.

Correspondence to: Dr. Mohamed E. Osman, The Department of Botany \& Microbiology, Faculty of Science, Helwan University, Egypt

\section{Introduction}

RECENTLY, disinfectants were used indiscriminately for cleanliness purposes. This led to bacterial adaptation to those products such as Quaternary Ammonium Compounds (QACs) and resistance of $\mathrm{P}$. aeruginosa isolates was frequently observed and adapted to QACs [1,2].

Benzalkonium Chloride (BC) is the most common QACs used. Their influence may not be limited to their areas of use, because it ultimately reaches the environment via wastewater and remains there for a long period, due to their poor biodegradability [3].

Pseudomonas aeruginosa is one of the most important nosocomial pathogens [4]. It causes several systemic infections, especially in immunosuppressed patients, and in patients with bed ulcers and severe burns [5-7]. Pseudomonas aeruginosa readily adapted to $\mathrm{BC}$ and consequently reducing their utility. The main mechanisms of resistance are mutations in the regulatory genes of the multidrug efflux pumps. Other mechanisms include mutations in GyrA and ParC genes that encode DNA GyrAse and topoisomerase IV respectively and the innate impermeability of the membrane $[\mathbf{8 , 9}]$.

High level of QACs exposure may induce a stress response leading to the expression of the SOS response, which could facilitate mutations in the Quinolone Resistance Determining Region (QRDR); the region where mutations arise in GyrA and ParC genes [3,10,11] . Mutations in QRDR, resulting in amino acid substitutions, alter the 
target protein structure and leading to $\mathrm{FQ} / \mathrm{BC}$ resistance $[12,13]$.

Like FQ, BC target DNA GyrAse, and topoisomerase IV by inhibiting their control of supercoiling within the cell. Which results in impaired DNA replication (at lower concentrations) and cell death (at lethal concentrations) [14,15].

Bacterial adaptation due to the exposure to antimicrobial agents includes some alterations of the outer membrane proteins [16]. Outer Membrane Proteins (OMPs) are necessary to cell viability because they are in the interface between the intra and extracellular parts of the cell and perform essential functions in various cellular processes such as cell adhesion, metabolites and ion transport, and endocytosis host immune responses [17]. Thus, OMPs are very important for pharmacological action and represent potential targets for vaccine development [18,19].

\section{Material and Methods}

This work was conducted at microbiology lab (B) in National Organization for Drug Control and Research along the period of 2015/2018.

\section{Bacterial isolates:}

Pseudomonas aeruginosa ATCC 15442 (purchased from Microbiologica USA) was used as a wild-type strain and isolate no. 87 (BC-adapted P. aeruginosa isolate) [20]

\section{PCR amplification and DNA sequencing of GyrA and ParC genes:}

The GyrA and ParC genes were PCR amplified with the pairs of primers as shown in (Table 1), according to Salma et al., [21], the PCR mixture, containing a 100ng of chromosomal DNA, $0.5 \mathrm{gM}$ concentration of each primer, and Dream taqTM green PCR Master Mix (Thermo-Fisher Scientific, USA) was heated for 3 minutes at $95^{\circ} \mathrm{C}$. Followed by 32 cycles of 30 seconds at $94^{\circ} \mathrm{C} ; 30$ seconds at $58^{\circ} \mathrm{C}(\mathrm{GyrA})$ and $55^{\circ} \mathrm{C}(\mathrm{ParC})$; and 60 seconds at $72^{\circ} \mathrm{C}$, with final 10 minutes extension step at $72^{\circ} \mathrm{C}$.

Table (1): Primers used in GyrA and ParC genes detection.

\begin{tabular}{ccl}
\hline Gene & Product size & \multicolumn{1}{c}{ Sequence } \\
\hline GyrA & 287 & Forward : GTGTGCTTTATGCCATGAG \\
& & Reverse : GGTTTCCTTTTCCAGGTC \\
ParC & 267 & Forward : CATCGTCTACGCCATGAG \\
& & Reverse : AGCAGCACCTCGGAATAG \\
\hline
\end{tabular}

The PCR products were purified with the DNA purifying kit (Thermo Fischer, USA) according to manufacturer's instructions. The sample was proc- essed with DNA sequencing kit (Thermo Fischer, USA) and sequenced by an automatic DNA sequencer (Applied Biosystem- serial no. G: 43A: 39T: 30C: 41) in order to analyze mutation in genes. Sequencing was carried out in Biotechnology lab, VACSERA, Dokki, Egypt. The DNA sequences were aligned and homology searches were performed using BLAST program (www.ncbi.nlm.nih. gov/blast) and the translation to amino acids was performed using ExPASy translate https://web. expasy.org/translate/

Phenotypic detection of outer membrane permeability:

Assessment of BC-adapted isolate for outer membrane permeability was performed by determination of the Minimum Inhibitory Concentration (MIC) value for Benzalkonium Chloride (BC) in the presence and absence of Disodium ethylenediaminetetraacetate (EDTA).

EDTA was used as a permeabilizer which chelates divalent cations that stabilize molecular interactions in the outer membrane causing disruption of Outer Membrane Proteins (OMPs). To avoid the effect of EDTA on bacterial growth, it was used at a concentration of ${ }^{1} / 4 \mathrm{MIC}$ and less. A fourfold reduction in the $\mathrm{BC}$ MIC or more in the presence of EDTA indicates outer membrane reduced permeability activity [22].

As described previously the MICs of EDTA carried out by using microtiter method [23] and the MIC of BC-EDTA were determined by agar dilution method according to CLSI (M100-S25) guidelines [24]. To evaluate the effect of the combinations, the Fractional Inhibitory Concentration (FIC) index was calculated [25]

\section{Outer membrane proteins analysis:}

\section{Extraction of outer membrane proteins:}

Outer Membrane Proteins (OMPs) of both wildtype strain ATCC 15442, treated isolate (isolate no. 87 treated with sub-MIC of EDTA + BC) and untreated isolate (isolate no. 87 without treatment) were extracted according to Yehia et al. [26].

Bacterial inoculum was incubated at $37^{\circ} \mathrm{C}$ for 48 hours in $100 \mathrm{~mL}$ of Tryptic Soya broth. The collected cells after centrifugation $(6,000 \mathrm{Xg}$ for 10 minutes at $4^{\circ} \mathrm{C}$ Sigma laboratory centrifuge $3 \mathrm{k} 30$, UK) were suspended in $3 \mathrm{~mL}$ of HEPES (10mM, pH 7.4), and disrupted by sonication (FALC Italy UTA-60, 45 seconds at $50 \%$ output). Cell debris was discarded by centrifugation at 
$6,000 \mathrm{Xg}$ for 10 minutes at $4^{\circ} \mathrm{C}$. Then the supernatant was added to $0.75 \mathrm{~mL}$ of $2 \% \mathrm{~N}$-lauroylsarcosine and kept at room temperature for 10 minutes. The detergent- solubilized OMPs were recovered by centrifugation at $100,000 \mathrm{Xg}$ for 1 hour (SorvallTM MTX 150 Micro-Ultracentrifuge, Thermo Fisher Scientific, 34,500rpm). Proteins pellet was resuspended in $3 \mathrm{~mL}$ of $10 \mathrm{mM}$ HEPES (pH 7.4), incubated with 1 volume of sarkosyl for 20 minutes at room temperature, and recovered by ultracentrifugation as explained before. Finally, the pellet was resuspended in $1 \mathrm{~mL}$ of $10 \mathrm{mM}$ HEPES and stored at $-20^{\circ} \mathrm{C}$.

\section{Protein content determination:}

The protein content of OMPs was determined as $\mathrm{g} / \mathrm{dL}$ using colorimetric method (Biuret reagentSpectrum Kit).

Determination of molecular weight of OMPs bands:

The molecular weight of OMPs bands was determined by using Sodium dodecyl sulfatepolyacrylamide gel electrophoresis (SDS-PAGE, Biorad) according to Laemmli [27]. The OMPs were solubilized in $0.05 \mathrm{M}$ Tris-HC1 buffer $(2.5 \%$ SDS, 5\% 2-mercaptoethanol, 25\% glycerol, and $0.003 \%$ bromophenol blue) and incubated at $100^{\circ} \mathrm{C}$ for 7 minutes before inoculation to the stacking gel $(4 \%)$ using three concentration of separating gel $(8,10$ and $12.5 \%)$. The gel was stained by Coomassie blue staining and the observed protein bands were analyzed by Gel Documentation Software (GelDocu Advanced Ver. 3.0) for the determination of their molecular weight.

\section{Results}

Detection and sequencing of GyrA and ParC genes by PCR technique:

The Quinolone Resistant Determining Region (QRDR) of GyrA (287-bp) and ParC (267-bp) was amplified for the wild-type strain ATCC 15442 and the $\mathrm{BC}$-adapted isolate no. 87 using agarose gel electrophoresis to detect these genes Fig. (1) and then were sequenced for the gene mutation detection.

Figs. $(2,4)$ showed the nucleotides sequence alignment of GyrA and ParC genes of wild-type strain ATCC 15442 and isolate no. 87. While Figs. $(3,5)$ showed the amino acids alignment of GyrA and ParC genes of wild-type strain ATCC 15442 and isolate no. 87.

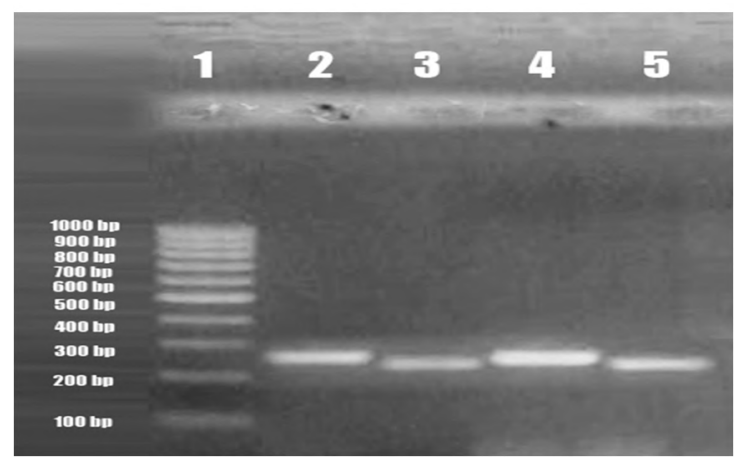

Fig. (1): Detection of GyrA and ParC genes by agarose gel electrophoresis of PCR-amplified products of the isolates was shown. Lane 1, DNA ladder; lanes $2 \& 4$ represent the amplified GyrA products for wild-type strain and the isolate no. 87 respectively and lanes $3 \& 5$ represent the amplified ParC products for wild-type strain and the isolate no. 87 respectively.

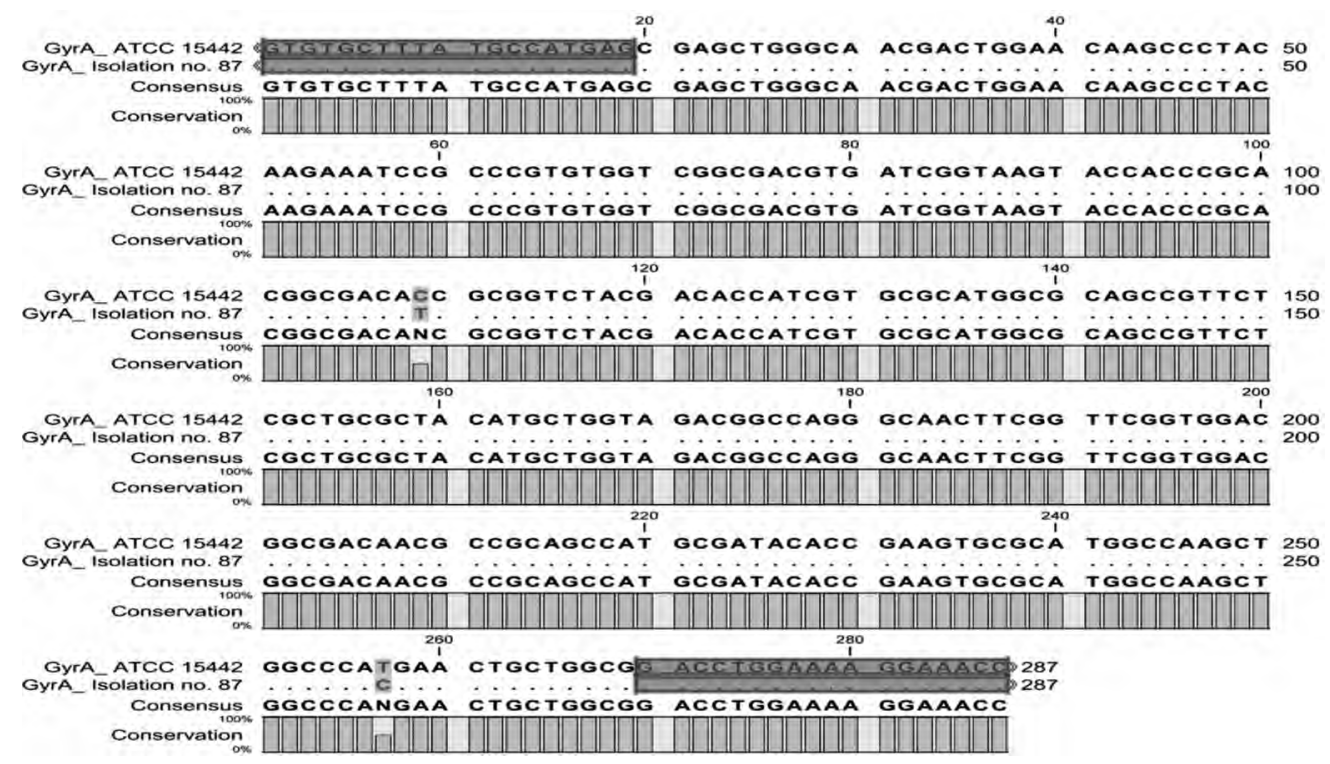

Fig. (2): Alignment of nucleotide sequences of the GyrA gene 


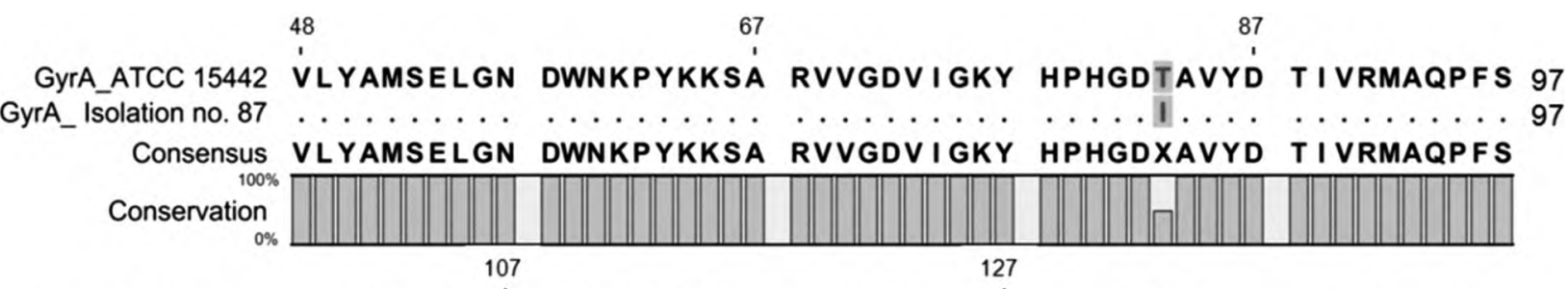

GyrA_ATCC 15442 LRYMLVDGQG NFGSVDGDNA AAMRYTEVRM AKLAHELLAD LEKET 142

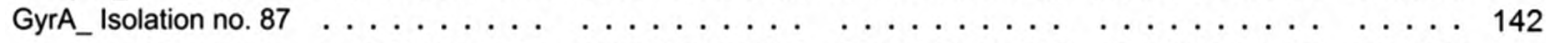
Consensus LRYMLVDGQG NFGSVDGDNA AAMRYTEVRM AKLAHELLAD LEKET Conservation

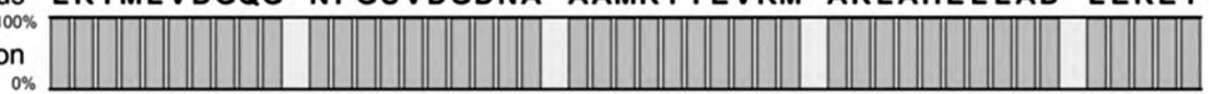

Fig. (3): Alignment of amino acid sequences of the GyrA gene.

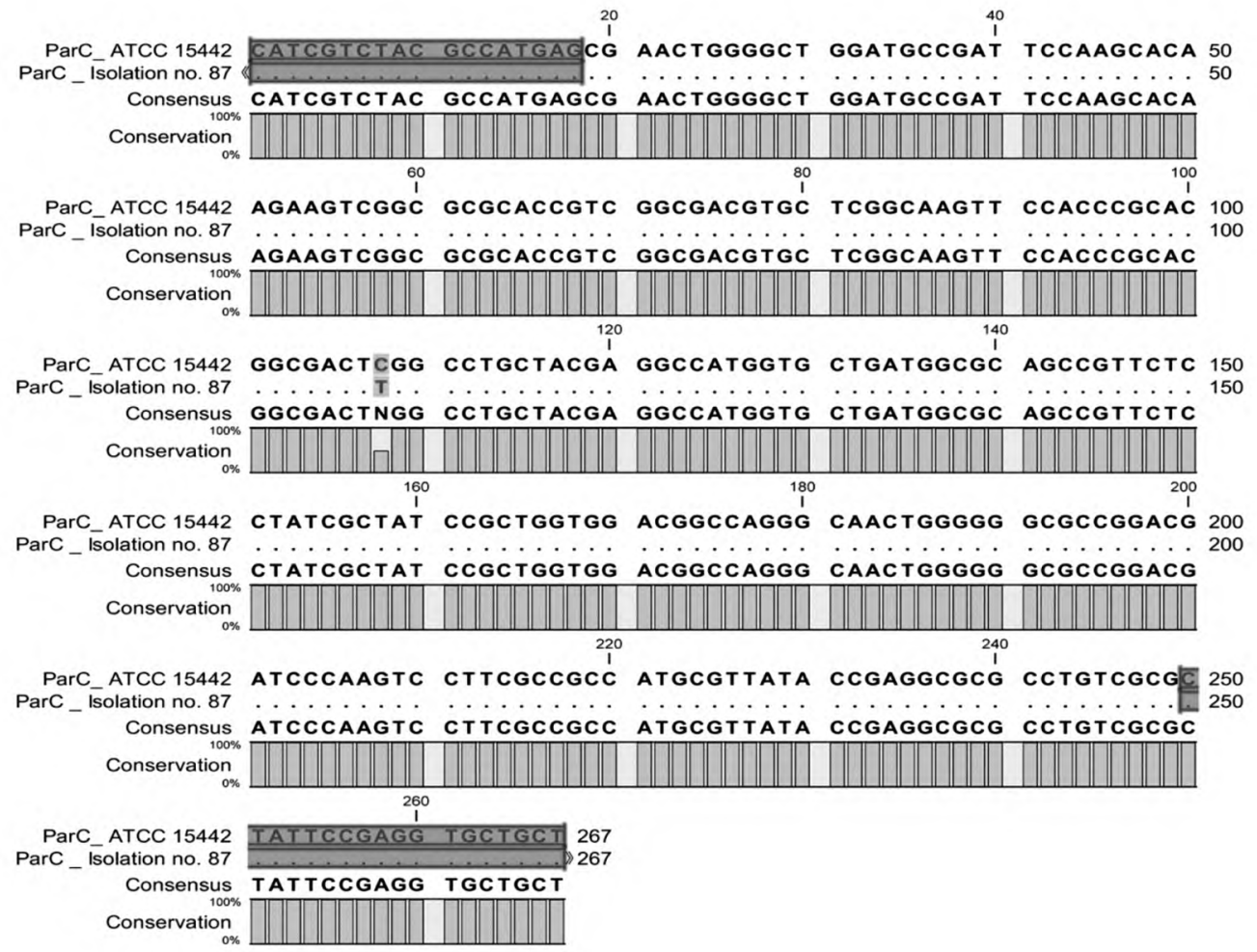

Fig. (4): Alignment of nucleotide sequences of the ParC gene.

$52 \quad 71 \quad 91$

ParC_ATCC 15442 IVYAMSELGL DADSKHKKSÁ RTVGDVLGKF HPHGDSACYÉ AMVLMAQPFS 101

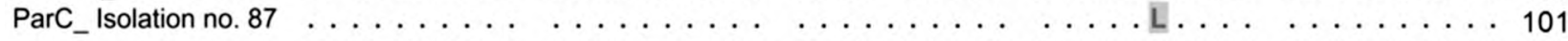

Consensus IVYAMSELGL DADSKHKKSA RTVGDVLGKF HPHGDXACYE AMVLMAQPFS

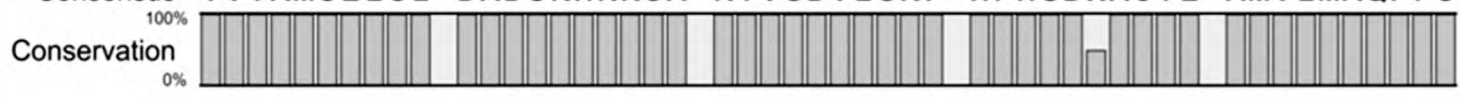

111

ParC_ATCC 15442 YRYPLVDGQG NWGAPDDPKS FAAMRYTEAR LSRYSEVL 139

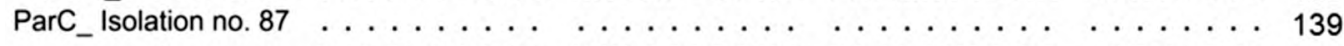

Consensus YRYPLVDGQG NWGAPDDPKS FAAMRYTEAR LSRYSEVL

Conservation

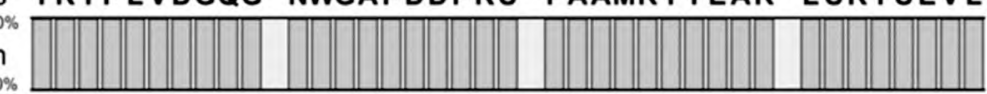

Fig. (5): Alignment of amino acid sequences of the ParC gene. 
The obtained results in (Table 2), showed a single mutation in codon 83 of the GyrA gene and in codon 87 of the ParC gene, which substitutes the amino acid profile from Threonine to Isoleucine and Serine-to Leucine, respectively.

Phenotypic detection of outer membrane permeability:

Disodium Ethylenediaminetetraacetate (EDTA) was used for phenotypic detection of OMPs; generally, EDTA increased the effect of different antimicrobial agents as it reduced their MICs. The MIC of BC decreased in the presence of EDTA $(512 \mathrm{mg} / \mathrm{L})$ from 2048 to $256 \mathrm{mg} / \mathrm{L}$.

Fractional inhibitory concentration index values in (Table 3), stated a synergistic antimicrobial activity of BC-EDTA (FIC <0.5) against the BCadapted isolate (no. 87).

\section{Outer membrane proteins analysis:}

Protein content determination:

Results in (Table 4), illustrated the OMPs contents $(\mathrm{g} / \mathrm{dL}$ ) of the wild-type (ATCC 15442), isolate no. 87 with and without treatment. The results indicated that the OMPs contents were approximately constant in all samples.

Determination of molecular weight of OMPs bands:

The separation of OMPs on SDS-PAGE was done using three different concentrations of polyacrylamide gel $(8,10 \& 12.5 \%)$. The gel was run three times for each concentration to confirm the results. Concentration $10 \%$ of polyacrylamide gel gave the best separation of the OMPs for the samples.

Results in (Table 5) and Fig. (6), indicated the molecular weight, intensity and the amount (\%) of outer membrane proteins extracted from ATCC 15442, 87 (treated) and 87 (untreated) at conc. $10 \%$, respectively using SDS-PAGE analysis.

Table (2): Type of point mutation in GyrA and ParC genes of P. aeruginosa isolate no. 87.

\begin{tabular}{lcll}
\hline Gene & Codon & Mutation & Amino acid substitution \\
\hline GyrA & 83 & ACC ---- ATC & Threonin -- Isoleucine \\
ParC & 87 & TCG =-z= TTG & Serine =- Leucine \\
\hline
\end{tabular}

Table (3): Fractional inhibitory concentration index (FIC index) of benzalkonium chloride and EDTA.

\begin{tabular}{|c|c|c|c|c|c|c|}
\hline \multirow{2}{*}{$\begin{array}{l}\text { Identified } \\
\text { resistant } \\
\text { isolates }\end{array}$} & \multirow{2}{*}{$\begin{array}{c}\text { Type } \\
\text { of } \\
\text { biocide }\end{array}$} & \multicolumn{2}{|c|}{ MIC of biocide } & \multirow{2}{*}{$\begin{array}{c}\text { FIC } \\
\text { of each } \\
\text { biocide }\end{array}$} & \multirow{2}{*}{$\begin{array}{l}\text { FIC } \\
\text { index }\end{array}$} & \multirow{2}{*}{ Outcome } \\
\hline & & Alone & $\begin{array}{c}\text { In } \\
\text { combination }\end{array}$ & & & \\
\hline Isolate no. & $\mathrm{BC}$ & 2048 & 256 & 0.125 & 0.169 & Synergy \\
\hline 87 & EDTA & 11630 & 512 & 0.044 & & \\
\hline
\end{tabular}

BC : Benzalkonium Choride.

EDTA : Disodium Ethylenediaminetetraacetate

Table (4): Outer membrane content of the wild-type strain (ATCC 15442), untreated and treated isolate no. 87.

\begin{tabular}{lc}
\hline Sample name & $\begin{array}{c}\text { OMP } \\
\text { content } \\
(\mathrm{gm} / \mathrm{dL})\end{array}$ \\
\hline Wild-type strain ATCC 15442 & 4.10 \\
Isolate no.87 (untreated) & 4.33 \\
Isolate no. 87 (treated with 256mg/l BC + 256mg/l EDTA) & 4.12 \\
\hline
\end{tabular}

Table (5): Molecular weights, intensity and amount $\%$ of extracted outer membrane proteins of the tested P. aeruginosa ATCC15442, BC-adapted isolate no. 87 treated with sub-MICs of EDTA and BC and without treatment.

\begin{tabular}{|c|c|c|c|c|c|c|c|c|c|c|c|c|c|c|c|c|}
\hline \multirow{2}{*}{ Band } & \multicolumn{4}{|c|}{ Marker } & \multicolumn{4}{|c|}{ ATCC 15442} & \multicolumn{4}{|c|}{87 (Treated) } & \multicolumn{4}{|c|}{87 (Untreated) } \\
\hline & $* \mathrm{Mol} \mathrm{Wt}$ & Intensity & Area & $\%$ & Mol Wt & Intensity & Area & $\%$ & Mol Wt & Intensity & Area & $\%$ & Mol Wt & Intensity & Area & $\%$ \\
\hline 1 & 245 & 747384 & 2640 & 6.14 & - & - & - & - & - & - & - & - & - & - & - & - \\
\hline 2 & 165 & 812592 & 2640 & 6.67 & - & - & - & - & & & & & - & - & - & - \\
\hline 3 & 125 & 889944 & 2640 & 7.31 & - & - & - & - & 120.83 & 671760 & 2160 & 4.56 & - & - & - & - \\
\hline 4 & 93 & 869880 & 2640 & 7.14 & & & & & $\begin{array}{l}90.89 \\
79.72\end{array}$ & $\begin{array}{l}673704 \\
683208\end{array}$ & $\begin{array}{l}2160 \\
2160\end{array}$ & $\begin{array}{l}4.57 \\
4.64\end{array}$ & $\begin{array}{l}- \\
-\end{array}$ & $\begin{array}{l}- \\
-\end{array}$ & $\begin{array}{l}- \\
-\end{array}$ & $\begin{array}{l}- \\
-\end{array}$ \\
\hline 5 & 72 & 1042008 & 2640 & 8.56 & 72.95 & 751192 & 2480 & 9.07 & 71.44 & 695736 & 2160 & 4.72 & - & - & - & - \\
\hline 6 & 57 & 986568 & 2640 & 8.1 & 52.23 & 2315328 & 6944 & 27.97 & $\begin{array}{l}52.23 \\
44.58\end{array}$ & $\begin{array}{l}1403568 \\
1721736\end{array}$ & $\begin{array}{l}4536 \\
5184\end{array}$ & $\begin{array}{l}9.53 \\
11.7\end{array}$ & 52.23 & 1237768 & 4216 & 100 \\
\hline 7 & 42 & 934560 & 2640 & 7.67 & & & & & & & & & - & - & - & - \\
\hline & & & & & $\begin{array}{l}39.11 \\
36.32 \\
32.44\end{array}$ & $\begin{array}{l}753672 \\
678032 \\
1525696\end{array}$ & $\begin{array}{l}2480 \\
2232 \\
4960\end{array}$ & $\begin{array}{l}9.1 \\
8.19 \\
18.43\end{array}$ & $\begin{array}{l}38.48 \\
36.01 \\
33.3\end{array}$ & $\begin{array}{l}718200 \\
744120 \\
1875960\end{array}$ & $\begin{array}{l}2160 \\
2160 \\
5400\end{array}$ & $\begin{array}{l}4.87 \\
5.05 \\
12.7\end{array}$ & $\begin{array}{l}- \\
- \\
-\end{array}$ & $\begin{array}{l}- \\
- \\
-\end{array}$ & $\begin{array}{l}- \\
- \\
-\end{array}$ & $\begin{array}{l}- \\
- \\
-\end{array}$ \\
\hline 8 & 31 & 986832 & 2640 & 8.1 & & & & & 28.91 & 732456 & 2160 & 4.97 & - & - & - & - \\
\hline $\begin{array}{l}9 \\
10\end{array}$ & $\begin{array}{l}24 \\
18\end{array}$ & $\begin{array}{l}1040160 \\
1032240\end{array}$ & $\begin{array}{l}2640 \\
2640\end{array}$ & $\begin{array}{l}8.54 \\
8.48\end{array}$ & $\begin{array}{l}26.92 \\
20.56\end{array}$ & $\begin{array}{l}755160 \\
744248\end{array}$ & $\begin{array}{l}2480 \\
2480\end{array}$ & $\begin{array}{l}9.12 \\
8.99\end{array}$ & $\begin{array}{l}26.17 \\
24.14\end{array}$ & $\begin{array}{l}1151712 \\
902232\end{array}$ & $\begin{array}{l}3672 \\
2808\end{array}$ & $\begin{array}{l}7.82 \\
6.12\end{array}$ & $\begin{array}{l}- \\
- \\
-\end{array}$ & $\begin{array}{l}- \\
- \\
-\end{array}$ & $\begin{array}{l}- \\
- \\
-\end{array}$ & $\begin{array}{l}- \\
- \\
-\end{array}$ \\
\hline $\begin{array}{l}10 \\
11\end{array}$ & $\begin{array}{l}10 \\
15\end{array}$ & 991320 & $\begin{array}{l}2040 \\
2640\end{array}$ & $\begin{array}{l}0.40 \\
8.14\end{array}$ & - & - & - & - & $\begin{array}{l}16.12 \\
12.49\end{array}$ & $\begin{array}{l}683856 \\
684288\end{array}$ & $\begin{array}{l}2160 \\
2160\end{array}$ & $\begin{array}{l}4.64 \\
4.64\end{array}$ & $\begin{array}{l}- \\
-\end{array}$ & $\begin{array}{l}- \\
-\end{array}$ & $\begin{array}{l}- \\
-\end{array}$ & $\begin{array}{l}- \\
-\end{array}$ \\
\hline $\begin{array}{l}12 \\
13\end{array}$ & $\begin{array}{l}8 \\
3.5\end{array}$ & $\begin{array}{l}996600 \\
84928\end{array}$ & $\begin{array}{l}2640 \\
2640\end{array}$ & $\begin{array}{l}8.18 \\
6.9\end{array}$ & 7.17 & 755160 & 2480 & 9.12 & 6.35 & 1390824 & 4536 & 9.44 & $\begin{array}{l}- \\
-\end{array}$ & $\begin{array}{l}- \\
-\end{array}$ & $\begin{array}{l}- \\
-\end{array}$ & $\begin{array}{l}- \\
-\end{array}$ \\
\hline
\end{tabular}

*Mol Wt: Molecular Weight. 


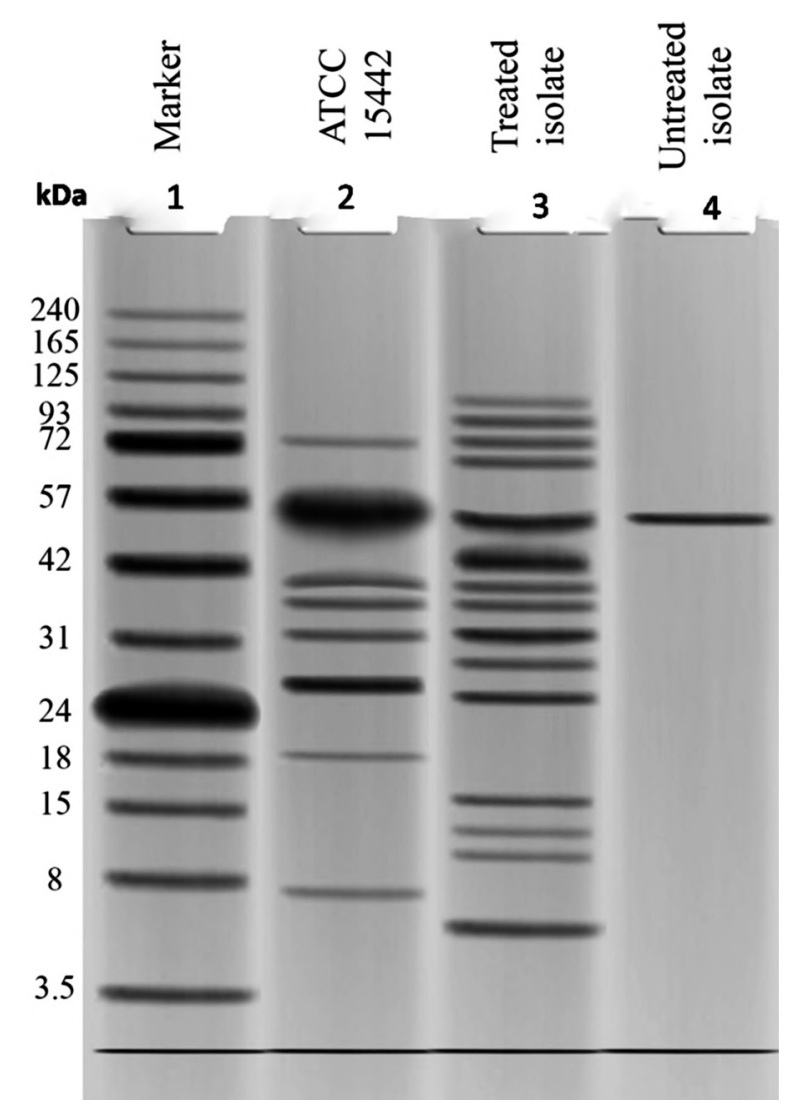

Fig. (6): Outer membrane proteins banding pattern of the wild-type (ATCC 15442), isolate no. 87 with and without treatment. Lane 1: Marker, lane 2: ATCC 15442, lane 3: Isolate 87 (treated), and lane 4: Isolate 87 (untreated) with $256 \mathrm{mg} \mathrm{BC} / 256 \mathrm{~mL}$ EDTA.

Results showed one band with molecular weight of $52.23 \mathrm{kDa}$ was detected in both treated and untreated isolate, as well as in wild-type strain ATCC 15442. In addition, seven bands with molecular weights of $71.44,38.48,36.01,33.03$, $26.17,21.14$ and $6.35 \mathrm{kDa}$ were stable in both ATCC 15442 and treated isolate. Also, seven bands with molecular weights $120.83,90.89,79.72,44.58$, $28.91,16.12$ and $12.49 \mathrm{kDa}$ were detected in the treated isolate.

On the other hand, the results illustrated the intensity and total amount (\%) of OMPs detected. It indicated that the amount of band 52.23 decreased in untreated isolate compared to ATCC strain 15442 and treated isolate. The down-regulation of the protein bands in untreated isolate may be due to the high adaptation to benzalkonium chloride.

Results of mutual bands illustrated that the intensity of most OMPs increased in treated isolate compared to wild-type strain ATCC 15442 except two bands with molecular weight of 71.44 and $38.48 \mathrm{kDa}$.

\section{Discussion}

The results of mutations detected in GyrA and ParC genes are consistent with previous reports on clinical isolates of $\mathrm{P}$. aeruginosa adapted to $\mathrm{BC}$ [28-31]

This was also consistent with the results of other studies as Gorgani et al., [32] who revealed that mutations related to antibiotic resistance were detected in codons 83 and 87 of GyrA, also Salma et al., [21] reported that among 38 isolates, 11 were susceptible, 22 were resistant, and 5 were intermediate to ciprofloxacin. They found that $19(50 \%)$ of these strains had a mutation in the GyrA gene (Thr 83 Ile), the ciprofloxacin-sensitive strains had no mutations in the sequence area examined. Also they found that $81.8 \%$ of the isolates that were resistant to ciprofloxacin had a mutation in the GyrA gene. So Thr-83 $\rightarrow$ Ile was shown to be the chief mechanism of fluoroquinolones resistance. This observation confirmed that the DNA gyrase was the primary target for fluoroquinolone resistance in the clinical isolates of P. aeruginosa [30].

Tohidpour et al., [28] reported that the substitution of Threonine (polar) to Isoleucine (non-polar) increase $\mathrm{FQ} / \mathrm{BC}$-adaptation due to its influence in the GyrAse-FQ/BC interaction by the loss of necessary enzyme-BC contacts.

In a previous study, isolate no. 87 has a mutation in the MexR (regulatory gene MexAB-OprM efflux system) in the codon 126 (substituting amino acid Valine to Glutamic acid) [20]. It was supposed that mutation in mexR gene may not reduce the susceptibility of the bacteria alone but when it co-occurs with a mutation on the GyrA gene [8,29]

The 52.23 protein band was previously reported as oprM protein which is responsible for the efflux pump activity [33,34]. In addition, seven bands with molecular weights of $71.44,38.48,36.01,33.03$, $26.17,21.14$ and $6.35 \mathrm{kDa}$ were were similar to those published earlier as opr C, E, F, R, G, H and I, respectively [19,35-37].

OprC and OprE are anaerobic-inducible porins, although it is conceivable that low levels of these small-channel porins may be present in wild-type cells $[33,38-40]$ OprF is a major outer membrane protein in $\mathrm{P}$. aeruginosa, which have a nonspecific porin function and binds to the underlying peptidoglycan [39,41-43]. Clinical isolates of $P$. aeruginosa that are multiply antibiotic resistant and deficient in the major outer membrane protein OprF have been obtained $[\mathbf{1 9 , 3 3 , 3 9 , 4 4 , 4 5 ]}$. OprR is an outer membrane associated protein with molecular mass $26 \mathrm{kDa}$. The actual function of OprR is not yet clear 
[1]. OprG was first investigated by Yates et al., [46] various groups suggested a link between the presence of OprG and resistance of P. aeruginosa to antibiotics because increased resistance to norfloxacin, kanamycin, and/or tetracycline was associated with the disappearance or downregulation of OprG $[19,36,47,48]$. While OprH is a gated porin for divalent cations $[33,49]$. Lipoproteins, like OprI has been shown to play a role in many fundamental cellular processes and in the pathogenesis of Psudomonas aeruginosa strains, where OprI was down-regulated in adapted P. aeruginosa for BC [50-52]. As an integral OM component, OprI plays a role in cell shape and membrane fluidity maintenance [53]. According to Linares et al., [54], the exposure of $\mathrm{P}$. aeruginosa to tobramycin and ciprofloxacin also promoted the down-regulation of the OprI gene.

Also, seven bands with molecular weights $120.83,90.89,79.72,44.58,28.91,16.12$ and $12.49 \mathrm{kDa}$ were detected in the treated isolate. The induction of protein with high molecular weight could be attributed to iron-limited conditions (EDTA is a chelating agent) $[\mathbf{2 2 , 2 6 , 5 5 ]}$

\section{Conclusion:}

Finally, the continuous increase in the prevalence of BC-adapted isolates could be attributed to the widespread use and misuse of these products. This resistance is mainly due to over-expression of efflux pump activity, the presence of mutations in the quinolone targets (DNA gyrase and topoisomerase IV) and alteration of OMPs.

This study complements the identification of adaptation mechanisms of $\mathrm{P}$. aeruginosa to $\mathrm{BC}$ and revealed that mutations in the GyrA and ParC genes and alternation in OMPs co-operated with efflux pump over-expression in the adaptation of $\mathrm{P}$. aeruginosa to $\mathrm{BC}$, which also confirm the presence of cross-resistance between BC and FQ genetically.

The present results also confirm previous findings regarding to obtain a combination of Benzalkonium Chloride plus efflux pump inhibitor or outer membrane permeabilizer which can be used pharmaceutically to restore disinfectant activity and minimize further developments of resistant strains.

\section{References}

1- TABATA A., NAGAMUNE H., MAEDA T., MURAKAMI K., MIYAKE Y. and KOURAI H.: Correlation between resistance of Pseudomonas aeruginosa to quaternary ammonium compounds and expression of outer membrane protein OprR. Antimicrob Agents Chemother [Internet]. 2003 Jul. [cited 2018 Oct. 20], 47 (7): 2093-9. Available from: http://www.ncbi.nlm.nih.gov/pubmed/12821452.

2- ANTONIO G., GADEA R. and ANGEL M.: Effects of exposure to quaternary-ammonium-based biocides on antimicrobial susceptibility and tolerance to physical stresses in bacteria from organic foods ndez Fuentes, Rub e n P e. 63, 2017.

3- BUFFET-BATAILLON S., TATTEVIN P., MAILLARD J.Y., BONNAURE-MALLET M. and JOLIVET-GOUGEON A.: Efflux pump induction by Quaternary Ammonium Compounds (QAC) and fluoroquinolone-resistance in bacteria, 1-23. Available from: http:// orca.cf.ac.uk/ 84361/3/Efflux pump induction by Quaternary Ammonium Compounds \%28QAC\%29 and fluoroquinolone-resistance in bacteria.pdf, 2016.

4- PRAKASH D. and SAXENA R.S.: Prevalence and antimicrobial susceptibility pattern Of Pseudomonas aeruginosa isolated from urine Samples of hospitalized patients in India. J. Appl. Pharm. Sci., 3 (1): 132-44, 2013.

5- ABD EL-TAWAB A.A., EL-HOFY F.I., KHATER D.F. and AL-ADL M.M.: Virulence, Resistance Genes Detection and Sequencing of gyrA Gene of Pseudomonas aeruginosa Isolated from Chickens and Human in Egypt. Nat. Sci., 16 (2): 32-9, 2018.

6- ALOUSH V., NAVON-VENEZIA S., SEIGMAN-IGRA Y., CABILI S. and CARMELI Y.: Multidrug-resistant Pseudomonas aeruginosa: Risk factors and clinical impact. Antimicrob Agents Chemother [Internet]. Jan. [cited 2018 Oct. 20], 50 (1): 43-8. Available from: http://www. nbi.nlm. nih.gov/pubmed/16377665, 2006.

7- GAD G.F., EL-DOMANY R.A., ZAKI S. and ASHOUR H.M.: Characterization of Pseudomonas aeruginosa isolated from clinical and environmental samples in Minia, Egypt: Prevalence, antibiogram and resistance mechanisms. J. Antimicrob. Chemother [Internet]. Sep. 17 [cited 2018 Oct. 20], 60 (5): 1010-7. Available from: http://www. ncbi.nlm.nih.gov/pubmed/17906321, 2007.

8- GORGANIA N., AHLBRANDC S., PATTERSONC A. and POURMANDA N.: Detection of point mutations associated with antibiotic resistance in Pseudomonas aeruginosa, 34 (5): 414-8, 2010.

9- JALAL S., CIOFU O., HOIBY N., GOTOH N. and WRETLIND B.: Molecular mechanisms of fluoroquinolone resistance in Pseudomonas aeruginosa isolates from cystic fibrosis patients. Antimicrob Agents Chemother [Internet]. Mar. 1 [cited 2018 Oct. 20], 44 (3): 710-2. Available from: http://www.ncbi.nlm.nih.gov/pubmed/ 10681343, 2000.

10- YOSHIDA H., BOGAKI M., NAKAMURA M., YAMANAKA L.M. and NAKAMURA S.: Quinolone resistance-determining region in the DNA gyrase gyrB gene of Escherichia coli. Antimicrob Agents Chemother [Internet]. Aug. [cited 2018 Oct. 20], 35 (8): 1647-50. Available from: http://www.ncbi.nlm.nih.gov/pubmed/1656869, 1991.

11- YOSHIDA H., BOGAKI M., NAKAMURA M. and NAKAMURA S.: Quinolone resistance-determining region in the DNA gyrase gyrA gene of Escherichia coli. Antimicrob Agents Chemother [Internet]. Jun. [cited 2018 Oct. 20], 34 (6): 1271-2. Available from: http://www. ncbi.nlm.nih.gov/pubmed/2168148, 1990.

12- HOOPER D.C.: New Uses for New and Old Quinolones and the Challenge of Resistance. Clin. Infect. Dis. [Internet]. Feb. 1 [cited 2018 Oct. 20], 30 (2): 243-54. Available from: http://www.ncbi.nlm.nih.gov/pubmed/10671323, 2000 
13-PIDDOCK L.J.: Mechanisms of fluoroquinolone resistance: An update 1994-1998. Drugs [Internet]. [Cited 2018 Oct. 20], 58 Suppl 2: 11-8. Available from: http://www. ncbi.nlm.nih.gov/pubmed/10553699, 1999.

14- DRLICA K., HIASA H., KERNS R., MALIK M., MUSTAEV A. and ZHAO X.: Quinolones: Action and resistance updated. Curr. Top. Med. Chem. [Internet]. [Cited 2018 Oct. 20], 9 (11): 981-98. Available from: http:// . www.ncbi.nlm.nih.gov/pubmed/19747119. 2009.

15- DRLICA K.: Mechanism of fluoroquinolone action. Curr Opin. Microbiol. [Internet]. Oct. [cited 2018 Oct. 20]; 2 (5): 504-8. Available from: http://www.ncbi.nlm. nih.gov/ pubmed/10508721, 1999.

16-FERNÁNDEZ L., BREIDENSTEIN E.B.M. and HANCOCK R.E.W.: Creeping baselines and adaptive resistance to antibiotics. Drug Resist Updat [Internet]. Feb. 1 [cited 2018 Oct. 20], 14 (1): 1-21. Available from: https://www. sciencedirect.com/science/article/pii/S1368764611000021, 2011.

17- RABILLOUD T.: Membrane proteins and proteomics: Love is possible, but so difficult. Electrophoresis [Internet]. Jun. 1 [cited 2018 Oct. 20], 30 (S 1): S174-80. Available from: http://doi.wiley.com/10.1002/elps.200900050, 2009.

18- SANTONI V., MOLLOY M. and RABILLOUD T.: Membrane proteins and proteomics: Un amour impossible? Electrophoresis [Internet]. Apr. 1 [cited 2018 Oct. 20], 21 (6): 1054-70. Available from: http://doi.wiley.com/ $10.1002 / \% 28$ SICI\%291522-2683\%2820000401\%$2921 \% 3$ A6\%3C $1054 \% 3$ A\%3AAID-ELPS $1054 \%$ 3E3.0.CO\%3B2-8, 2000.

19- MACHADO I., COQUET L., JOUENNE T. and PEREIRA M.O.: Proteomic approach to pseudomonas aeruginosa adaptive resistance to benzalkonium chloride. J. Proteomics [Internet]. 89: 273-9. Available from: http://dx.doi.org/ 10.1016/j.jprot.2013.04.030, 2013.

20- OSMAN M.E.S., EL-HENDAWY H.H., ABDEL-ALL S.M., HASSAN A.M. and MAHMOUD D.E.: Correlation between Resistance of Pseudomonas aeruginosa to Benzalkonium Chloride and Expression of efflux pump genes. J. Appl. Pharm. Sci., 2018.

21- SALMA R., DABBOUSSI F., KASSAA I., KHUDARY R. and HAMZE M.: GyrA and parC mutations in quinolone-resistant clinical isolates of Pseudomonas aeruginosa from Nini Hospital in north Lebanon. J. Infect. Chemother. [Internet]. 19 (1): 77-81. Available from: http://dx.doi.org/ 10.1007/s10156-012-0455-y, 2013.

22- HISHAM A.A., AMIRA M.E.G. and HEND A.K.: Phenotypic and genotypic detection of antibiotic resistance of Pseudomonas aeruginosa isolated from urinary tract infections Phenotypic and genotypic detection of antibiotic resistance of Pseudomonas aeruginosa isolated from urinary tract infections. (March): 10-21, 2018.

23- WIEGAND I., HILPERT K. and HANCOCK R.E.W.: Agar and broth dilution methods to determine the Minimal Inhibitory Concentration (MIC) of antimicrobial substances. Nat. Protoc. [Internet]. Feb. 1 [cited 2018 Mar. 17], 3 (2): 163-75. Available from: http://www.nature.com/ articles/nprot.2007.521, 2008.

24- CLSI: Clinical and Laboratory Standards institute. Performance Standards for Antimicrobial Susceptibility Testing; 25 th ed Informational Supplement; Wayne, Pennsylvania. CLSI document m100-s25, 2015.
25- SATISH, ROBERT C.M.J. and M.E.G.: Antimicrobial combinations. In: Lorian. V.: Antibiotics in laboratory medicine. $5 \mathrm{t}^{\mathrm{h}}$ ed. pp. 366-425, p. pages. new York: Williams \& Wilkins. [Internet]. Lippincott Williams \& Wilkins; [cited 2018 May 7]. Available from: https://. books.google.com.eg/books/about/Antibiotics in Laborat ory_Medicine.html?id=HdA4dl8m_T4C\&redir_esc=y, 2005.

26- YEHIA H.M., HAS SANEIN W.A. and IBRAHEIM S.M.: Studies on molecular characterizations of the outer membrane proteins, lipids profile, and exopolysaccharides of antibiotic resistant strain Pseudomonas aeruginosa. Biomed. Res. Int., 2015 (February), 2015.

27- LAEMMLI U.K.: Cleavage of structural proteins during the assembly of the head of bacteriophage T4. Nature, 227 (5259): 680-5, 1970.

28- TOHIDPOUR A., PEERAYEH S.N. and NAJAFI S.: Detection of DNA Gyrase Mutation and Multidrug Efflux Pumps Hyperactivity in Ciprofloxacin Resistant Clinical Isolates of Pseud-omonas aeruginosa, 1 (1): 1-7, 2013.

29- SAVOV E., TRIFONOVA A., TODOROVA I., GERGOVA I., BORISOVA M., ANANIEVA M., et al.: Assesment Of The Resistance Of Clinical Isolates Pseudomonas Aeruginosa To Quinolonones, 12 (3): 221-6, 2014.

30- NOURI R., AHANGARZADEH M. and HASANI A.: The role of gyrA and parC mutations in fluoroquinolonesresistant Pseudomonas aeruginosa isolates from Iran. Brazilian J. Microbiol. [Internet]. 47 (4): 925-30. Available from: http://dx.doi.org/10.1016/j.bjm.2016.07.016, 2016.

31- NEJMA M. BEN, SIOUD O. and MASTOURI M.: Quinolone-resistant clinical strains of Pseudomonas aeruginosa isolated from University Hospital in Tunisia. 3 Biotech, $1-7,2018$.

32- GORGANI N., AHLBRAND S., PATTERSON A. and POURMAND N.: Detection of point mutations associated with antibiotic resistance in Pseudomonas aeruginosa. Int. J. Antimicrob. Agents [Internet]. Nov. [cited 2018 Oct. 20], 34 (5): 414-8. Available from: http://www.ncbi. . nlm.nih.gov/pubmed/19656662. 2009.

33- HANCOCK R.E.W. and BRINKMAN F.S.L.: Function of Pseudomonas Porins in Uptake and Efflux. Annu. Rev. Microbiol. [Internet]. Oct. [cited 2017 Dec. 31], 56 (1): 17-38. Available from: http://www.ncbi.nlm.nih.gov/ pubmed/12142471, 2002.

34- HAMZEHPOUR M.M., PECHERE J.C., PLESIAT P. and KOHLER T.: OprK and OprM define two genetically distinct multidrug efflux systems in Pseudomonas aeruginosa. Antimicrob Agents Chemother., 39 (11): 2392-6, 1995.

35- TATTAWASART U., MAILLARD J.Y., FURR J.R. and RUSSELL A.D.: Outer membrane changes in Pseudomonas stutzeri resistant to chlorhexidine diacetate and cetylpyridinium chloride. Int. J. Antimicrob. Agents, 16 (3): 233-8, 2006.

36- McPHEE J.B., TAMBER S., BAINS M., MAIER E., GELLATLY S., LO A., et al.: The major outer membrane protein OprG of Pseudomonas aeruginosa contributes to cytotoxicity and forms an anaerobically regulated, cationselective channel. FEMS Microbiol Lett., 296 (2): 2417, 2009.

37- CHEVALIER S., BOUFFARTIGUES E., BODILIS J., MAILLOT O., LESOUHAITIER O., FEUILLOLEY 
M.G.J., et al.: Structure, function and regulation of Pseudomonas aeruginosa porins. FEMS Microbiol Rev., 41 (5): 698-722, 2017.

38- HANCOCK R.E.: Resistance mechanisms in Pseudomonas aeruginosa and other nonfermentative gram-negative bacteria. Clin. Infect. Dis. [Internet], 27: 93-9. Available from: http://www.ncbi.nlm.nih.gov/pubmed/9710677, 1998.

39- HANCOCK R. and WOROBEC E.: Pseudomonas: Outer membrane proteins. In: Biotechnology Handbooks, p. 139-67, 1998

40- YONEYAMA H. and NAKAE T.: Protein C (OprC) of the outer membrane of Pseudomonas aeruginosa is a copper-regulated channel protein. Microbiology, 142 (8): 2137-44, 1996.

41- BELLIDO F., MARTIN N.L., SIEHNEL R.J. and HANCOCK R.E.W.: Reevaluation, using intact cells, of the exclusion limit and role of porin OprF in Pseudomonas aeruginosa outer membrane permeability. J. Bacteriol., 174 (16): 5196-203, 1992.

42- RAWLING E.G., BRINKMAN F.S.L. and HANCOCK R.E.W.: Roles of the carboxy-terminal half of Pseudomonas aeruginosa major outer membrane protein $\mathrm{OprF}$ in cell shape, growth in low-osmolarity medium, and peptidoglycan association. J. Bacteriol., 180 (14): 355662, 1998.

43- WOODRUFF W.A. and HANCOCK R.E.W.: Pseudomonas aeruginosa outer membrane protein $\mathrm{F}$ : Structural role and relationship to the Escherichia coli omP protein. J. Bacteriol., 171 (6): 3304-9, 1989.

44- PUMBWE L., EVERETT M.J., HANCOCK R.E.W. and PIDDOCK L.J.V.: Role of gyrA mutation and loss of OprF in the multiple antibiotic resistance phenotype of Pseudomonas aeruginosa G49. FEMS Microbiol Lett., 143 (1): 25-8, 1996.

45- BRATU S., LANDMAN D., GUPTA J. and QUALE J. Role of AmpD, OprF and penicillin-binding proteins in (3-lactam resistance in clinical isolates of Pseudomonas aeruginosa. J. Med. Microbiol., 56 (6): 809-14, 2007.

46- YATES J.M., MORRIS G. and BROWN M.R.W.: Effect of iron concentration and growth rate on the expression of protein $\mathrm{G}$ in Pseudomonas aeruginosa. FEMS Microbiol. Lett., 58 (2-3): 259-62, 1989.
47- CHAMBERLAND S., BAYER A.S., SCHOLLAARDT T., WONG S.A. and BRYAN L.E.: Characterization of mechanisms of quinolone resistance in Pseudomonas aeruginosa strains isolated in vitro and in vivo during experimental endocarditis. Antimicrob Agents Chemother., 33 (5): 624-34, 1989.

48- PENG X., XU C., REN H., LIN X., WU L. and WANG S.: Proteomic analysis of the sarcosine-insoluble outer membrane fraction of Pseudomonas aeruginosa responding to ampicillin, kanamycin, and tetracycline resistance. J. Proteome. Res., 4: 2257-65, 2005.

49- MACFARLANE E.L.A., KWASNICKA A., OCHS M.M. and HANCOCK R.E.: PhoP-PhoQ homologues in Pseudomonas aeruginosa regulate expression of the outermembrane protein OprH and polymyxin B resistance. Mol. Microbiol., 34 (2): 305-16, 1999.

50- De VOS D., BOUTON C., SARNIGUET A., De VOS P., VAUTERIN M. and CORNELIS P.: Sequence diversity of the oprI gene, coding for major outer membrane lipoprotein I, among rRNA group I pseudomonads. J. Bacteriol., 180 (24): 6551-6, 1998.

51- RAU H., REVETS H., CORNELIS P., TITZMANN A., RUGGLI N., McCULLOUGH K.C., et al.: Efficacy and functionality of lipoprotein OprI from Pseudomonas aeruginosa as adjuvant for a subunit vaccine against classical swine fever. Vaccine, 24 (22): 4757-68, 2006.

52- QIN X., EMERSON J., STAPP J., STAPP L., ABE P. and BURNS J.L.: Use of real-time PCR with multiple targets to identify Pseudomonas aeruginosa and other nonfermenting gram-negative bacilli from patients with cystic fibrosis. J. Clin. Microbiol., 41 (9): 4312-7, 2003.

53- GUYARD-NICODÈME M., BAZIRE A., HÉMERY G., MEYLHEUC T., MOLLÉ D., ORANGE N., et al.: Outer membrane modifications of Pseudomonas fluorescens MF37 in response to hyperosmolarity. J. Proteome. Res., 7 (3): 1218-25, 2008.

54- LINARES J., GUSTAFSSON I. and BAQUERO F.: J.M. Antibiotics as intermicrobial signaling agents instead of weapons. Proc. Natl. Acad. Sci. U.S.A., 103: 19484-9, 2006.

55- MIZUNO T. and KAGEYAMA M.: Separation and Characterization aeruginosa of the Outer Membrane of Pseudomonas aeruginosa. J. Biochem., 84 (1): 179-91, 1978.

\section{التغيرات فى بروتينات الغشاء الخارجى والطفرات فى جينات GyrA و و ParC

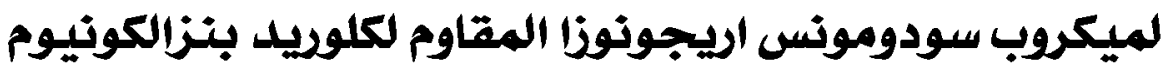

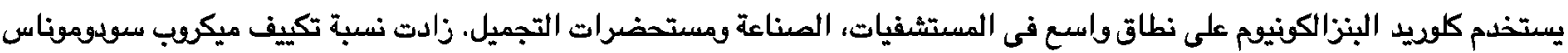

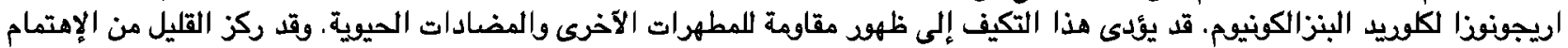

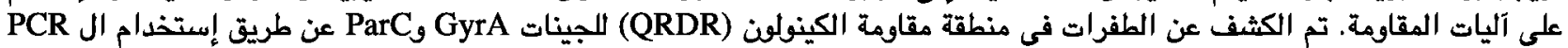

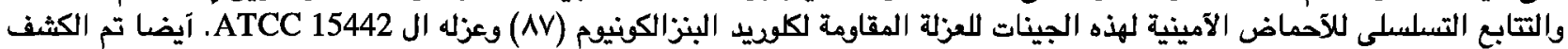

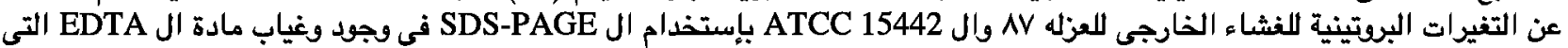

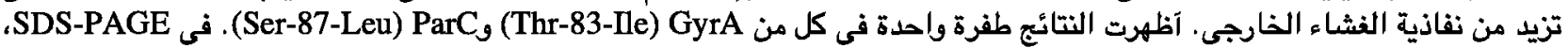

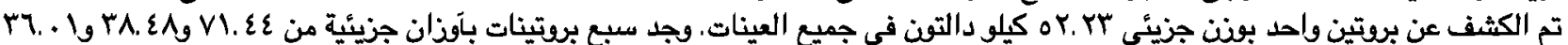

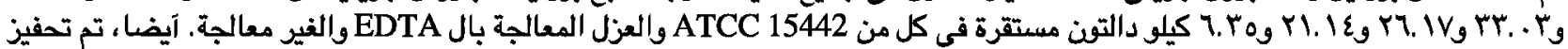

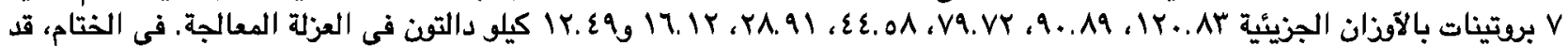

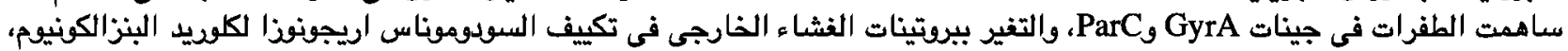

